\title{
Особливості поведінки та взаємин дітей у сучасному суспільстві
}

Анотація. У статті на основі емпіричного матеріалу аналізується вплив комп 'ютерних ігор на поведінку та взаємини дітей 5-7 років. Розглядаються можливі причини порушення процесу деиентраиії у дітей в умовах компютерно-ігрової діяльності.

Децентрачія в основному залежить від зовнішніх умов розвитку індивіда й найбільш активно розвивається у дитячій сюжетно-рольовій грі. Виявляється, що затримання децентраиії в дошкільників призводить не тільки до конфліктів з однолітками та дорослими, а й негативно впливає на прочес формування особистості дитини, закріплює таки риси характеру, як домінантність, нечуйність, егоїзм. Доводиться, що заміна традииійної рольової гри комп 'ютерним сурогатом затримує розвиток децентраиії у сучасних дітей.

Ключові слова: дещентращія, дошкільники, егочентризм, діти, рольова гра, комп'ютерні ігри.

Актуальність. Інформаційні і комп'ютерні технології суттєво перебудовують практику повсякденного життя. Ці тенденції виявляються навіть в таких традиційних сферах, як гра й іграшки. Розвиток індустрії електронних і комп'ютерних ігор ставить перед психологією нові питання: про те, як такі ігри впливають на розвиток дитини, чи можна цю діяльність назвати грою, у яких стосунках вона знаходиться з традиційною сюжетно-рольовою грою.

Як відомо, найбільш інтенсивний період становлення головних психологічних новоутворень припадає на дошкільний i молодший шкільний вік, причому однією 3 найважливіших умов їхнього формування виступає рольова гра.

Враховуючи наростаючу експансію комп'ютерних ігор у середовище дошкільників і тенденцію до витіснення традиційної рольової гри $з$ життя дитини, гостро встає проблема компенсації дефіциту традиційної гри за допомогою використання ігор комп'ютерних, і про вплив останніх на розвиток особистості дошкільника, а зокрема, на розвиток децентрації.

За нашими спостереженнями, діти в дитячому садку усе рідше грають у сюжетно-рольові ігри. Причини цього явища, ми вважаємо, криються, насамперед, у невмінні дітей спілкуватися з однолітками, егоцентризмі, а також у тому, що на вільну гру у дитячому садку відводиться усе менше часу.

Додаткові заняття $з$ логіки, іноземних мов, танців чудово доповнюють програму дитячого садка, проте багато батьків записують дітей у всі гуртки одразу і у них просто не залишається часу на гру. Проте ігрові переживання, почуття й емоції $є$ важливою стороною життя дитини, i, якщо дитина не може отримати їх у традиційній рольовій грі, вона звертається до сурогату — гри комп’ютерної.

Метою нашого дослідження було з'ясувати чи впливає на поведінку дітей і стосунки їх 3 ровесниками заміна традиційної сюжетно-рольової гри комп'ютерною грою.

Насамперед для 3'ясування міри залучення дітей 5-7 років у світ комп'ютерних ігор, визначення комп'ютерних ігор, яким віддається перевага, і кількості часу, який діти проводять за комп'ютером, нами було проведене опитування батьків дітей старших груп ДНЗ №303 і 1-их класів СШ № 209 у м. Києві. Опитано 71 батька. Анкета охоплювала різні сторони життя і діяльності дітей. Серед питань анкети батькам пропонувалося відповісти й на такі:

1. 3 якого віку дитина грає в комп'ютерні ігри? 
2. Скільки часу на день дитина грає в комп'ютерні ігри?

3. Які комп'ютерні ігри більше всього подобаються дитині?

4. Як часто дитина спостерігає за процесом гри дорослих у комп’ютерні ігри?
5. Які улюблені традиційні ігри дитини?

6. Чи впливає комп’ютерна гра на поведінку дитини і як?

Результати опитування наведенні в Таблиці 1.

Таблиия 1

\begin{tabular}{|l|c|c|c|c|}
\hline Вік дитини & $\begin{array}{c}\text { 5-6 років } \\
\text { ДН3 }\end{array}$ & $\begin{array}{c}\text { 6 років } \\
\text { ДН3 }\end{array}$ & $\begin{array}{c}\text { 6-7 років } \\
\text { школа }\end{array}$ & $\begin{array}{c}\text { Середній показник, } \\
\text { \% }\end{array}$ \\
\hline Не грають & 35 & 12,5 & 27,5 & $\mathbf{2 5}$ \\
\hline Грають до 0,5 год/день & 26 & 50 & 46 & $\mathbf{4 1}$ \\
\hline До години на день & 13 & 17 & 12,5 & $\mathbf{1 4}$ \\
\hline До 1,5 год/день & 9 & 12,5 & 9 & $\mathbf{1 0}$ \\
\hline 2 год і більше & 17 & 8 & 6 & $\mathbf{1 0}$ \\
\hline
\end{tabular}

3 результатів видно, що 10\% дітей 5-7 років проводять, граючи в комп'ютерні ігри більше 2 годин на день, $10 \%$ - більше години на день, $14 \%-30-60$ хвилин на день, $41 \%$ - від 2 до 4 годин на тиждень і лише $25 \%$ взагалі не грають.

Найбільш залучені до комп'ютерних ігор 6-річні діти. Ми вважаємо, що це пов'язане з тим, що вони краще орієнтуються у віртуальному просторі, ніж 5-річні діти, і мають у своєму розпорядженні більше вільного часу, ніж школярі.

Серед дітей, які не грають в комп'ютерні ігри, дівчаток в 2 рази більше, ніж хлопчиків. А серед дітей, що грають більше години на день - хлопчиків в 2 рази більше, ніж дівчаток. Дівчатка частіше грають в спокійні, розвиваючі і навчальні ігри та ігри за мотивами мультфільмів. Хлопчики віддають перевагу більш активним іграм - гонкам, стратегіям, симуляторам.

Комп'ютер - чудовий партнер по спілкуванню: завжди розуміє (якщо тиснеш на ті кнопки), не вередує, не конфліктує, не читає нотацій. Взагалі, $з$ ним легко домовитися, не те що з реальним партнером. Тому діти, які мають труднощі в спілкуванні, віддають перевагу віртуальному світу. Створюється замкнене коло: гра 3 комп'ютером не дає змогу навчитись правильним стратегіям у взаємовідносинах 3 ровесниками, а труднощі у спілкуванні 3 ровесниками штовхають дитину до частішої взаємодії з віртуальним світом.

Ми порівняли кількість звертань до психолога із приводу труднощів у спілкуванні дітей з їхньою захопленістю комп'ютерними іграми. Виявилося, що $80 \%$ дітей, які грають у комп'ютерні ігри більше 1 години на день, мають проблеми поведінки і спілкування $з$ ровесниками. Найбільш популярні комп'ютерні ігри даної групи дітей — «стрілялки», перегони, стратегії. Рідше зустрічаються ігри за мотивами мультфільмів.

Розглянемо декілька випадків і спробуємо з'ясувати причини проблемної поведінки дітей.

Єлисей К., 6 років, родина повна, благополучна. Дитячий садок почав відвідувати тільки $з$ цього року. Період адаптації до дитячого садка проходив важко - вранці у дитячому садку сильно кричав, плакав. 3 дітьми увесь час влаштовував бійки, дряпався, штовхався. Друзів не має. Загальні вимоги вихователя виконує, але при зверненні дорослого до нього особисто, впадає «у ступор», весь напружується й робить «страшне обличчя».

Тактильного контакту 3 дорослими 3 бридливістю уникає. Рухи поривчасті, сильно гримасує, кривляється. Слисей у віці 3 років потрапив у лікарнюз обструктивним бронхітом i, щоб скрасити дитині дозвілля, батьки подарували їй PSP 3 комп'ютерними іграми. 3 того часу комп'ютер став основною й улюбленою іграшкою хлопчика. Ігри, яким віддається перевага, - військові «стрілялки». Про себе Єлисей говорить: «Я - солдат!» і поводиться 3 дітьми відповідно до прийнятої ролі. У колективних іграх хлопчик не бере участь, переважно 
бігає й «стріляє» 3 іграшки, що заміняє зброю, відштовхує інших дітей, якщо вони зустрічаються на його шляху.

Тільки на другому занятті із психологом пішов на контакт. Розслабився, розповів про свою домашню кішку. У пісочниці побудував «Країну звірів», де всі звірі «були добрі, допомагали один одному, і ніхто нікого не їв». Із завданням методики «Родина звірів» не впорався — намалював кішку, сказав: «Тільки її люблю». На пропозицію психолога представити себе м'ячиком, відреагував 3 нерозумінням і сторожкістю.

Після проведення анкетування батьків з'ясувалося, що хлопчик щодня грає в комп'ютер 1,5-2 години, улюблена гра - військова стратегія.

3 огляду на вищесказане, можна припустити, що труднощі в спілкуванні Єлисея 3 дітьми викликані не агресивністю хлопчика, як могло здатися спочатку (агресія була ситуативна й носила захисний характер), а сильною центрацією. Центрація означає, що дитина може бачити увесь світ тільки зі своєї точки зору, ніяких інших точок зору для неї не існує. Подолання «пізнавального егоцентризму» відбувається, згідно Д.Б. Ельконіна, у рольовій колективній грі. Переключення 3 однієї ролі на іншу в різноманітних іграх дітей, перехід 3 позиції дитини на позицію дорослого приводить до систематичного «розхитування» уявлень дитини про абсолютність свого положення у світі речей і людей та створює умови для координації різних позицій. У Єлисея не було можливості виробити децентровану позицію, з огляду на домашнє виховання, епізодичне спілкування з дітьми та комп’ютерні ігри як альтернативу спілкуванню з дорослими.

Інший випадок. Микита К., 5,5 років. Відвідує дитячий садок 33 років. Родина повна, благополучна. Хлопчик часто хвоpiє, сором'язливий, боязкий. Розмовляти почав тільки торік, що суттєво утруднило його контакти $з$ однолітками. На заняттях пасивний, практично не відповідає. Їсть дуже повільно й довго, як би відтягаючи момент контакту з дітьми. У групі ні з ким не дружить, у колективну гру його прийма- ють рідко, тому що він не завжди правильно розуміє правила гри. Періодично може бігати за ким-небудь 3 дітей, але не граючи $з$ ним, а просто повторюючи його рухи. Але в основному грає наодинці, найчастіше в конструктор.

За допомогою до психолога звернулася вихователька, стривожена ізольованістю дитини.

При бесіді Микита бентежився, говорив так тихо, що важко було розібрати слова. Коли раптом помітив комп'ютер у кабінеті - оживився, сказав, що й у нього вдома такий же. Про комп'ютерні ігри розповідав натхненно. Виявилося, що знає їх цілу безліч і щодня проводить за комп'ютером досить багато часу. Проблеми 3 мовою й слабким здоров'ям не сприяли розвитку комунікабельності Микити, а комп'ютер на тривалий період замінив йому друзів.

Методика «Родина звірів». Намалював одного черв'яка — «це мій улюблений звір, інші не вийшли». На прохання психолога представити себе чарівником i озвучити заповітне бажання — відповів: «Хочу стати дорослим і придумувати ігри для комп'ютера».

Даний випадок яскраво демонструє перевагу, яку віддає дитина іграм у віртуальній реальності над контактами з однолітками. На наслідки, які пов'язані з раннім залученням до комп'ютерної гри, вказує провідний фахівець в галузі психосемантики і комп'ютерної психодіагностики, А.Г. Шмельов: «Умовність світу сучасних комп'ютерних ігор... вимагає надзвичайного обмеження в доступі до них дошкільників, аж до повного виключення в окремих випадках - доки не сформувався Образ Реального Світу, як інтеграційна основа елементарного здорового глузду, вплив умовних ігор може виявитися у випадку вразливої дитини, певною мірою «шизофренізуючим». В усякому разі, нерідко дитина застрягає на етапі дитячого АУТИЗМУ й ЕГОЦЕНТРИЗМУ: виявляється не чутливою до реальних вимог реального світу дорослих» [4, с. 332].

Проте, як свідчать дані анкетування, далеко не всі батьки повною мірою пред- 
ставляють наслідки надмірного захоплення дитиною іграми у віртуальному просторі. $37 \%$ вважають, що комп'ютерні ігри ніяк не впливають на поведінку дитини, $56 \%$ переконані в позитивному впливі комп'ютера і лише $13 \%$ батьків відзначають такі негативні прояви у поведінці дітей, як знервованість, вередливість, відчуженість.

Одними 3 перших звертають увагу на зміни в поведінці дітей вчителі початкових класів. Вони відзначають неадекватну поведінку деяких першокласників. I хоча Данило С., Микита В., Богдан Т. і Ярік Д. вчаться в різних класах, претензії вчителів до них практично однакові.

Ці діти відмовляються виконувати вимоги вчителя на уроці, займаються тільки тим, що їм цікаво, можуть під час уроку ходити класом, відволікають інших дітей і не реагують на зауваження. 3 однолітками в них часто виникають непорозуміння, які переростають у конфлікти.

Поглиблена діагностика виявила, що у хлопців затримується формування вміння вставати на позицію іншого, здатність враховувати думку партнера по спілкуванню, координувати свою діяльність.

Очевидно, труднощі спілкування цих дітей пов'язані з тим, що вони не можуть адекватно передавати свої повідомлення (i через це їх не розуміють навколишні), або не можуть точно сприймати відтінки повідомлень інших людей, що може зумовити неадекватність їх вчинків.

Як стало відомо 3 анкетування батьків, Данило і Ярік грають на день не менш 1 години в стратегії, Микита - 1,5 години в гонки. Тільки один Богдан з чотирьох хлопчиків не грає в комп'ютерні ігри (вдома немає комп'ютера).

Богдану 7 років, він - старша дитина в багатодітній родині. Авторитарний стиль виховання, застосування тілесних покарань, відчуття постійної загрози з боку батька виявляються як в тесті Розенцвейга, так і в бесіді з Богданом. Результати тесту Люшера свідчать про те, що незадоволена потреба в емоційній підтримці, теплоті, розумінні і любові викликає від- чуття занепокоєння і тривоги у хлопчика, навколишнє оточення й значимі стосунки $\epsilon$ джерелом постійної напруги. Внутрішні проблеми негативно впливають на здатність зосереджуватися, що в свою чергу породжує труднощі в навчанні. Згідно $з$ тестом Розенцвейга у Богдана переважають інтропунитивні реакції (47\%), що направлені на самого себе 3 прийняттям провини або ж відповідальності за виправлення виниклої ситуації, фруструюча ситуація не підлягає засудженню. В основному реакції захисного типу - активність у формі осудження кого-небудь, заперечення або визнання власної провини; ухиляння від докору, спрямовані на захист свого «я».

Психологічне неблагополуччя цього хлопчика в школі, що виявляється в порушенні дисципліни, ігноруванні розпоряджень вчителя, емоційній «виключеності» 3 життя класу є продовженням і відреагуванням родинних проблем, надмірної суворості виховання, частими тілесними покараннями.

Інший хлопчик, Микита В., 6,5 років, єдина улюблена дитина в повній благополучній родині. Але стосунки з однокласниками в Микити не складаються, з ним ніхто не хоче дружити, навіть сидіти за однією партою. Діти вважають, що він «шкодливий, противний і всіх ображає». Микита стверджує, що діти просто не розуміють його жартів, які треба відзначити, бувають досить жорстокими. За результатами тесту Люшера видно, що хлопчик зазнає труднощів в адаптації у колективі, шукає прихильності, дружби й розуміння оточуючих. Проявляє домінантність, прагнення до лідируючої позиції, запальність у конфліктних ситуаціях, нетерпимість до слабкості інших у міжособистісних контактах. Егоцентричний i образливий. Страждає здатність до концентрації уваги. Прагнення самоствердитися, підвищити самооцінку, підкреслити свою винятковість, домогтися поваги з боку оточуючих виступає як компенсація незадоволеної потреби в спілкуванні, дружбі. На питання тесту Розенцвейга намагався давати соціально бажані відповіді. У результаті переважали реакції 
інтропунитивного й імпунитивного напрямку самозахисного типу.

Основний шкільний конфлікт Микити проявляється у взаєминах з ровесниками. Хлопчик не вміє налагоджувати стосунки, входити в товариство однолітків, домовлятися з ними, висловлювати свої побажання та узгоджувати їх із бажаннями та намірами інших.

Гуртки й спортивні секції Микита не відвідує, друзів поза школою не має. Весь вільний час проводить з батьками або грає в комп'ютерні ігри. А для того, щоб усвідомити своє «Я», необхідна взаємодія думок. Ця взаємодія, вважав Ж. Піаже, спочатку неможлива між дитиною й дорослим, тому що нерівність занадто велика. Дитина намагається наслідувати дорослого і в той же час захищати себе від нього, а не обмінюватися думками. Тільки індивіди, що вважають один одного рівними можуть здійснювати «розвиваючий» взаємний контроль. Такі відносини з'являються 3 моменту встановлення кооперації серед дітей, частіше за все у рольовій грі.

3 огляду на вищесказане, дозволимо собі зробити припущення, що, у більшості випадків, витиснення сюжетно-рольової гри 3 життя дітей 5-7 років комп'ютерною грою негативно впливає на розвиток їхніх комунікативних навичок. В результаті у дітей можуть виникати складності із встановленням міжособистісних стосунків, 3 вираженням думок та емоцій.

Уміння достатньо точно виражати свої думки, а також розуміти повідомлення інших тісно пов'язане 3 рівнем розвитку децентрації. Поряд 3 імпульсивністю й недостатнім розвитком вольової сфери, егоцентризм стає вагомою причиною порушень поведінки.

Для того, щоб подолати егоцентризм, необхідні дві умови, вважав Ж. Піаже: перша - усвідомити своє «Я» у якості суб'єкта й відокремити суб'єкт від об'єкта; друга — координувати свою власну точку зору 3 іншими, а не розглядати іii, як єдино можливу [2].

«Розхитування» егоцентризму — одне 3 найважливіших виховних завдань дошкі- льного віку. Поступово, найчастіше в грі, відбувається координація егоцентричної позиції з позиціями інших учасників гри. У зв'язку з цим проходить й еволюція дитячих ігор - від гри «поруч, але не разом», до спільної гри, й, як до вершини - до гри за правилами. Егоцентризм поступається місцем децентрації, коли дитина навчається усвідомлювати своє «Я» як суб'єкт. Після цього вже можливе «відділення» суб' $є к-$ та від об'єкта, яке дозволяє співвідносити свою точку зору з позиціями інших людей. До кінця дошкільного віку в дитини повинне визріти вміння не розглядати свою позицію як єдино можливу [5].

Найбільш сприятливим середовищем для визрівання децентрованої позиції $\epsilon$ сюжетно-рольова гра, основним вмістом якої $є$ норми людських відносин. Саме рольова гра стає для дитини способом освоєння моральних норм. Лише у рольовій грі дитина отримує навички соціальної взаємодії, в цій взаємодії, в переходах «Я — я-в-ролі» і узгодженні «моя роль - роль партнера» відбувається пізнавальна й емоційна децентрація. Якщо процес децентрації затримується, егоцентризм нерідко стає причиною ускладнень міжособистісних контактів. Невміння врахувати точку зору іншого обертається конфліктами й самотністю. Подолання егоцентризму - одне із центральних завдань виховання. Його найважливіший механізм - формування в дитини здатності оцінювати ту чи іншу ситуацію з різних точок зору, терпимо ставитися до думок і суджень інших людей.

Перехід від егоцентризму до децентрації характеризує пізнання на всіх рівнях розвитку.

Для того, щоб цей перехід був можливий, потрібний особливий інструмент, за допомогою якого можна було б пов'язати факти між собою, здійснити децентрацію об'єктів стосовно сприйняття й власних дій.

Для активізації процесу децентрації необхідні різноманітні форми спільної діяльності дитини з дорослими й дітьми, в спілкуванні і різноманітній ігровій діяльності. У грі дитина весь час «обертається», змі- 
нює свою позицію. Одні й ті ж предмети постають перед нею з різних боків. Інакше кажучи, гра послуговує децентрації дітей, що сприяє становленню у них логічного мислення [5].

Затримання процесу децентрації в дошкільників призводить не тільки до конфліктів 3 однолітками та дорослими, а й негативно впливає на процес формування особистості дитини, закріплює таки риси характеру, як домінантність, нечуйність, егоїзм.

\section{Список використаних джерел:}

1. Обухова Л.Ф. Концепция Жана Пиаже: за и против / Л. Ф. Обухова. - М. : Изд-во МГУ, 1981. - $191 \mathrm{c}$.

2. Пиаже Ж. Речь и мышление ребенка / Жан Пиаже; [пер. с франц. и англ., сост., комм., ред. Перевода Вал. А. Лукова, Вл. А. Лукова]. - М. : Педагогика-Пресс, 1994. - 528 с. - (Серия: «Психология: классические труды»).

3. Флейвелл Джон Х. Генетическая психология Жана Пиаже / Джон Х. Флейвелл; [пер. с англ. М. Лисина и Л. Обухова; послесл. П. Я. Гальперина и Д.Б. Эльконина]. - М. : Просвещение, 1967. - $623 \mathrm{c}$.

4. Основы психодиагностики : учебное пособие для студентов педвузов / [Подред. А. Г. Шмелева]. - Москва ; Ростов-на-Дону : Феникс, 1996. — 544 с.

5. Эльконин Д.Б. Избранные психологические труды / Д. Б. Эльконин. - М. : Педагогика, 1989. - 534 c.

6. Чекстере О.Ю. Психологічні особливості децентрації дітей, залежних від комп'ютерноігрової діяльності : дис. канд. психол. наук / О. Ю. Чекстере. - Київ, 2012. - 303 с.

Аннотация. В статье на основании эмпирического материала анализируется влияние компьютерных игр на поведение детей 5-7 лет. Рассмотрены возможные причины нарушения проиесса децентраиии у детей в условиях компютерно-игровой деятельности.

Ключевые слова: децентрация, дошкольники, эгоцентризм, дети, ролевая игра, компьютерные игры.

Abstracts. The article (based on empirical data) analyzed the effect of computer games on the behavior and attitudes of children 5-7 years old. The possible causes of disturbance of decentration in a computer-gaming activities for children.

Development decentration depends on the maturation of the individual biological structures ( $\mathrm{Zh}$. Piazhe) as well as the external environmental conditions. If physiological laws still remain more or less constant, the external conditions have changed dramatically. And the biggest changes has undergone the environment in which the child develops.

Keywords: decentration, preschoolers, egocentrism, children, role playing, computer games. 